\title{
A review of coccidiosis in South American camelids
}

\author{
J. P. Dubey ${ }^{1}$
}

Received: 15 March 2018 / Accepted: 23 April 2018 / Published online: 26 May 2018

(C) This is a U.S. Government work and not under copyright protection in the US; foreign copyright protection may apply 2018

\begin{abstract}
Camelids (llamas, alpacas, vicuñas, guanacos) are important for the economy of South America and Eimeria infections are important as cause of mortality in camelids. Of the five most prevalent species of Eimeria in South American camelids, Eimeria macusaniensis, Eimeria lamae, Eimeria alpacae, Eimeria punoensis, and Eimeria ivitaensis, E. macusaniensis is considered the most pathogenic. There is considerable confusion concerning the endogenous developmental stages of Eimeria spp. in camelids. Many papers on camelid coccidiosis were published in local Peruvian journals, not easily accessible to wider audience. The objective of the present paper is to summarize information on history, validity of Eimeria species, life cycle, pathogenicity, prevalence, epidemiology, diagnosis, and control of coccidiosis in camelids.
\end{abstract}

Keywords Vicuñas $($ Lama vicugna $) \cdot$ Llamas $($ Lamaglama $) \cdot$ Alpaca $($ Lamapacos $) \cdot$ Guanacos $($ Lamaguanicoe $) \cdot$ Eimeria species

\section{Introduction}

The South American camelids consist of four species_-llamas (Lama glama), alpacas (Lama pacos), guanacos (Lama guanicoe), and vicuñas (Lama vicugna); their generic nomenclature is controversial. I have used the genus Lama for all four species. Traditionally, they are distributed at high altitudes (3600-5400 m) in South America where they are source of meat, hide, fiber, transport and their feces are used for fuel and fertilizer (Díaz et al. 2016). In many countries, such as the USA, they are reared for recreation and the commercial product is a live animal. Coccidiosis is an important cause of mortality in llamas and alpacas. There are many uncertainties concerning the life cycle of Eimeria species in camelids and early literature from Peru is in local journals, not easily accessible. The object of this review is to summarize information on coccidiosis in camelids.

Section Editor: Berit Bangoura

J. P. Dubey

jitender.dubey@ars.usda.gov

1 Beltsville Agricultural Research Center, Animal Parasitic Diseases Laboratory, United States Department of Agriculture, Agricultural Research Service, Building 1001, Beltsville, MD 20705-2350, USA

\section{Species of Eimeria in camelids}

There are five common species of Eimeria in South American camelids (Table 1). They are morphologically so different in size and shape that species can be identified without the need of sporulation (Fig. 1). Of these, E. macusaniensis and E. ivitaensis are one of the largest among species of Eimeria in general (Levine 1973).

The sporulation time differs among these Eimeria species. Eimeria macusaniensis oocysts take longer time to sporulate, perhaps related to the thickness of the oocyst wall. Temperature of incubation can also affect sporulation; E. macusaniensis oocysts sporulated in 9 days at $30^{\circ} \mathrm{C}$, in 21 days at $18-25^{\circ} \mathrm{C}$ but oocysts did not sporulate at $6-7{ }^{\circ} \mathrm{C}$ (Rohbeck 2006).

\section{History}

Eimeria macusaniensis oocysts are morphologically and biologically distinctive, resembling watermelon seed or a cut avocado; its oocysts are up to $107 \mu \mathrm{m}$ long, have a very thick wall, and prepatent period is $>30$ days. Examination of coprolites and llama mummies dating about 10,000 years (Halocene period) in Patagonia, Argentina found E. macusaniensis and E. ivitaensis oocysts (Martinson et al. 2003; Fugassa et al. 2008, 2010; Velázquez et al. 2014; Taglioretti et al. 2014, 
Table 1 Common species of Eimeria in South American camelids

\begin{tabular}{|c|c|c|c|c|c|}
\hline Character & E. macusaniensis & E. lamae & E. alpacae & E. punoensis & E. ivitaensis \\
\hline Oocyst shape & Ovoid, piriform & Ellipsoidal, ovoid & Ellipsoidal, ovoid & Ellipsoidal, ovoid & Ellipsoidal \\
\hline Size $^{a}$ & $\begin{array}{l}81-107 \times 61-80 \\
\mathbf{1 0 0}-\mathbf{1 1 0} \times \mathbf{7 7 - 8 4 ^ { b }}\end{array}$ & $\begin{array}{l}30-40 \times 21-30 \\
\mathbf{3 5}-\mathbf{3 8} \times \mathbf{2 6}-\mathbf{3 0}\end{array}$ & $\begin{array}{l}22-26 \times 18-21 \\
\mathbf{2 4 - 2 7} \times \mathbf{2 2}-\mathbf{2 4}\end{array}$ & $17-22 \times 14-18$ & $83.5-98.6 \times 49.3-59.1$ \\
\hline Mean & $\begin{array}{l}93.6 \times 67.4 \\
\mathbf{1 0 6 . 6} \times \mathbf{8 0 . 5}\end{array}$ & $\begin{array}{l}35.6 \times 24.5 \\
\mathbf{3 6 . 7} \times \mathbf{2 8 . 9}\end{array}$ & $\begin{array}{l}24.1 \times 19.6 \\
\mathbf{2 5 . 8} \times \mathbf{2 2 . 9}\end{array}$ & $19.9 \times 16.4$ & $88.8 \times 51.8$ \\
\hline Wall thickness & $8.3-11.4$ & $1.4-1.8$ & $1.2-1.6$ & $0.8-1.1$ & $4.0-4.5$ \\
\hline Micropylar cap & 2-5 high, 9-14 wide & $\begin{array}{l}\text { 1.5-2.2 high, } \\
8.8-11.4 \text { wide }\end{array}$ & $\begin{array}{l}0.7-1.3 \text { high, } \\
4.4-7.5 \text { wide }\end{array}$ & $\begin{array}{l}\text { 0.4-0.8 high, } \\
3.5-5.5 \text { wide }\end{array}$ & $\mathrm{Absent}^{\mathrm{c}}$ \\
\hline Sporocyst shape & Elongate & Elongate, ovoid & & Elongate, ovoid & Elongate \\
\hline Size range & $\begin{array}{l}33-40 \times 16-20 \\
\mathbf{4 4 - 4 8} \times \mathbf{2 0}-\mathbf{2 3}\end{array}$ & $\begin{array}{l}13-16 \times 8-10 \\
\mathbf{1 7 - 2 0} \times \mathbf{9 - 1 2}\end{array}$ & $\begin{array}{l}10-13 \times 7-8 \\
\mathbf{1 0 - 1 2} \times \mathbf{7}-\mathbf{9}\end{array}$ & $8-11 \times 5-7$ & $32.6-40.8 \times 11.9-13.6$ \\
\hline Mean & $\begin{array}{l}36.3 \times 18.3 \\
\mathbf{4 5 . 2} \times \mathbf{2 2 . 6}\end{array}$ & $\begin{array}{l}15.2 \times 8.5 \\
\mathbf{1 8 . 6} \times \mathbf{1 0 . 7}\end{array}$ & $\begin{array}{l}11.0 \times 6.8 \\
\mathbf{1 1 . 3} \times \mathbf{7 . 8}\end{array}$ & $9.2 \times 6.1$ & $35.4 \times 13.1$ \\
\hline Stieda body & Faint & Present & Faint & Faint & Not described \\
\hline Original host & Lama pacos & Lama pacos & Lama pacos & Lama pacos & Lama pacos \\
\hline Reference & Guerrero et al. (1971) & Guerrero $(1967 \mathrm{a}, \mathrm{b})$ & Guerrero $(1967 a, b)$ & Guerrero $(1967 \mathrm{a}, \mathrm{b})$ & Leguía and Casas (1998) \\
\hline
\end{tabular}

${ }^{\mathrm{a}}$ The measurements are in $\mu \mathrm{m}$. Guerrero $(1967 \mathrm{a}, \mathrm{b})$ measured 50 or more oocysts and sporocysts; the number of specimens measured by Leguia and Casas (1998) and Schrey et al. (1991) was not stated

${ }^{\mathrm{b}}$ Figures in bold are from oocysts in Lama glama (Schrey et al. 1991)

${ }^{\mathrm{c}}$ Absent in original description of Leguía and Casas (1998) but present in some oocysts (see Fig. 1)

2015); shape and sizes of these oocysts were remarkably preserved (Fugassa et al. 2008). Similar findings are reported for coprolites from Chile dating to Pre-Inca Hispanic Contact Period (de Souza et al. 2018).

Although coccidia have been recognized for more than two centuries (Levine 1973), little attention was paid to coccidia in camelids. Yakimoff (1934) in Leningrad, Russia first reported Eimeria infection in feces of one of the five llama fecal samples sent to him by Professor Iwanoff; nothing was said who collected samples and the locality. Yakimoff (1934) named the parasite, Eimeria peruviana, n.sp. The oocysts were 27.9$37.5 \times 18-22 \mu \mathrm{m}$ with $10.5-15.0 \times 7.5 \mu \mathrm{m}$ sporocysts, some oocysts had a micropyle but others did not. No other details were given. It appears that there was a mix up with other feces sent by Iwanoff because E. peruviana has not been found subsequently. Because there are no archived specimens, this question cannot be resolved retrospectively. I consider it nomen nudum/species enquirende.

As per Guerrero (1967a), Eimeria infections were reported in alpacas in Peru by Arnao (1951), Chávez (1959), Chávez and Guerrero (1960), Chávez (1965), and Vásquez et al. (1965); these papers were published in local journals or in conference proceedings and are no longer available because the files have been discarded (personal communication from Dr. Guillermo Leguía to me, January 10, 2018). As per Guerrero (1967a), Arnao (1951) first reported Eimeria sp. in feces of alpacas, and Chávez (1959) found Eimeria oocysts in $17 \%$ of 2109 fecal samples. Chávez and Guerrero (1960) found Eimeria in the intestine of an alpaca and in feces of $14 \%$ of 300 alpacas
(Chávez and Guerrero 1960). Vásquez et al. (1965) reported Eimeria oocysts in the intestine of llamas in Peru.

Carlos Antonio Guerrero (1967a, b) from Peru came to the University of Illinois, Urbana, Illinois, USA, and under the supervision of Professor Norman D. Levine, formally described and named the three species of Eimeria, E. alpacae, E. punoensis, and E. lamae. The samples had been collected from the rectum of 12 alpacas from an alpaca farm in Peru, mixed with $2.5 \%$ potassium dichromate or $10 \%$ formalin and sent to USA. Apparently, most oocysts had sporulated during transit thus, in the original published paper there was no description of unsporulated oocysts (Guerrero 1967b). However, unsporulated oocysts of E. alpacae and E. punoensis (but not E. lamae) were described in his thesis (Guerrero 1967a). After completing his graduate studies, Guerrero returned to Peru and together with Hernandez and Alva reported severe coccidiosis in a 5-month-old alpaca; the alpaca was in poor nutritional condition and had died a day before necropsy (Guerrero et al. 1967). It had mixed infection of E. lamae, E. alpacae, E. punoensis, and an unnamed Eimeria species. They also reported schizonts, gamonts, and oocysts in histological sections; the stages found were arbitrarily assigned to four species of Eimeria. Four years later, Guerrero et al. (1971) described and named Eimeria macusaniensis.

Guerrero et al. (1970b) also first reported on experimental infection of E. lamae in alpaca. Two alpacas were fed 100 oocysts (6 months-old alpaca \#1) or 100,000 oocysts (4 months old alpaca \#2). Both excreted E. lamae oocysts 10 days (alpaca \#2) or 16 days (alpaca \#1) later. Alpaca \#2 developed diarrhea and died day 15 post inoculation (p.i.). Small schizonts (not 


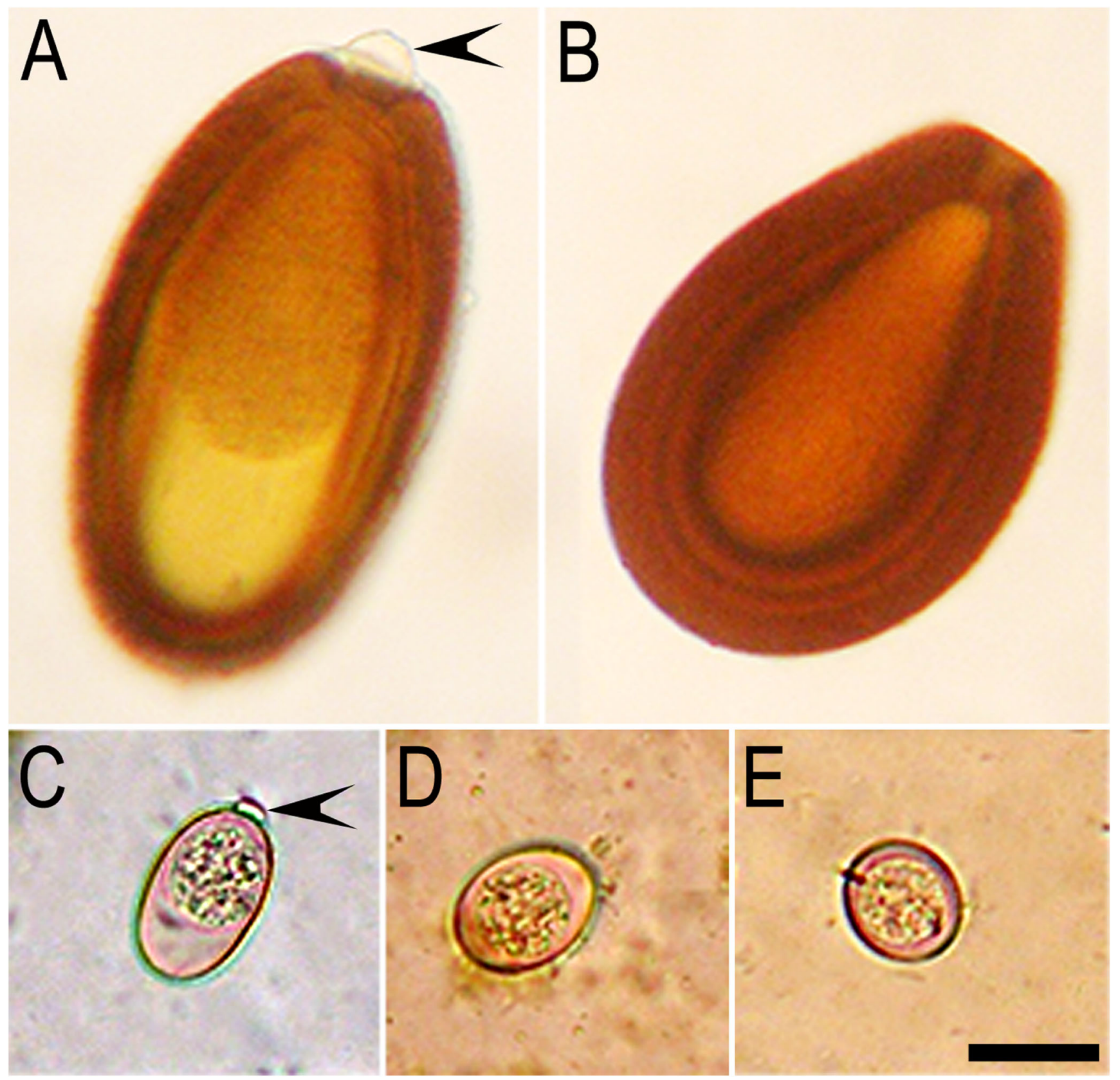

Fig. 1 Unsporulated oocysts of five common species of Eimeria in South American camelids. Unstained. Courtesy of Dr. M. M. Cafrune. A E. ivitaensis. B E. macusaniensis. C E. lamae. D E. alpace. E E. punoensis. Note micropylar caps (arrowheads). The scale bar $=20 \mu \mathrm{m}$ and applies to all parts

illustrated) were found in the duodenum, and numerous gamonts and oocysts were found throughout the small intestine at necropsy.

Three decades later, Leguia and Casas (1998) described the fifth species of Eimeria, E. ivitaensis (Table 1).

\section{Prevalence of Eimeria species oocysts in feces}

Prevalence data in llamas (Table 2), alpacas (Table 3), guanacos (Table 4) and vicuñas (Table 5) indicate these camelids are commonly infected with Eimeria species. The data from North America and South America camelids are grouped together but the patterns of infections might be different in these continents. In general, E. lamae was the most prevalent and E. ivitaensis was the least prevalent. Infections were most common in nursing animals. Up to $90 \%$ of cria under 2 months of age were found infected (Guerrero et al. 1971). It is noteworthy, that despite excretion of as many as 411,600 oocysts per gram of feces (opg), all vicuñas were asymptomatic (Cafrune et al. 2014). 
Table 2 Prevalence of Eimeria in Llama (Lama glama)

\begin{tabular}{|c|c|c|c|c|c|}
\hline Country, region & No. tested & No. positive (\%) & Eimeria species & Remarks & Reference \\
\hline \multicolumn{5}{|l|}{ Argentina } & \multirow{4}{*}{$\begin{array}{l}\text { Cafrune et al. } \\
\text { (2009) }\end{array}$} \\
\hline Jujuy & 478 & $233(48.7)$ & $\begin{array}{l}\text { E. macusaniensis in all, } \\
\text { mixed with E. ivitaensis in } 2\end{array}$ & $\begin{array}{l}1 \text { llama with mixed E. macusaniensis } \\
\text { and E. ivitaensis had diarrhea }\end{array}$ & \\
\hline Salta & 48 & $17(35.4)$ & E. macusaniensis in 17 & & \\
\hline Catamarca & 100 & $65(65)$ & $\begin{array}{l}\text { E. macusaniensis in all, } \\
\text { mixed with E. ivitaensis in } 2\end{array}$ & & \\
\hline Switzerland & $\begin{array}{l}293 \text { from } 38 \\
\text { farms }\end{array}$ & $(68)$ & E. macusaniensis & Only herd prevalence stated. & $\begin{array}{l}\text { Hertzberg and } \\
\text { Kohler (2006) }\end{array}$ \\
\hline \multicolumn{5}{|l|}{ USA } & \multirow{3}{*}{$\begin{array}{l}\text { Rickard and } \\
\text { Bishop (1988) }\end{array}$} \\
\hline \multirow[t]{2}{*}{ Oregon } & 189 adults & $69(37)$ & $\begin{array}{l}\text { E. alpacae }(27 \%) \text {, E. macusaniensis } \\
\quad(1 \%) \text { E. punoensis }(17 \%), \\
\text { E. lamae }(9 \%),\end{array}$ & $\begin{array}{l}1 \text { species in } 58 \%, 2 \text { species in } 38 \% \text {, } \\
3 \text { species in } 4 \% \text { in adults. }\end{array}$ & \\
\hline & 50 crias & $30(60)$ & $\begin{array}{l}\text { E. alpacae ( } 52 \%) \text {, } \\
\text { E. macusaniensis 0, E. punoensis } \\
(40 \%), \text { E. lamae }(32 \%) \text {, }\end{array}$ & $\begin{array}{l}\text { In crias, } 47 \% \text { contained } 2 \text { species, } \\
30 \% \text { had } 3 \text { species, } 23 \% \text { had } \\
1 \text { species. All animals were healthy. }\end{array}$ & \\
\hline 10 states & 301 & $36(12)$ & E. macusaniensis & $\begin{array}{l}<1 \text { year } 19 \text { of } 86(22.1 \%),>1 \text { year } 17 \\
\text { of } 200(8.5 \%)\end{array}$ & Jarvinen (1999) \\
\hline \multirow[t]{2}{*}{$\begin{array}{l}\text { Colorado and } \\
\text { Wyoming }\end{array}$} & 121 Colorado & $76(62.8)$ & $\begin{array}{l}\text { E. alpacae } 75, \text { E. macusaniensis } 0 \text {, } \\
\quad \text { E. lamae } 1\end{array}$ & 4 herds surveyed & \multirow[t]{2}{*}{$\begin{array}{l}\text { Schrey et al. } \\
\text { (1991) }\end{array}$} \\
\hline & 23 Wyoming & $15(65.2)$ & $\begin{array}{l}\text { E. alpacae 5, E. macusaniensis } 2 \text {, } \\
\text { E. lamae } 8,\end{array}$ & & \\
\hline
\end{tabular}

Table 3 Prevalence of Eimeria in alpacas (Lama pacos)

\begin{tabular}{|c|c|c|c|c|c|}
\hline Country-region & No. tested & No. positive (\%) & Eimeria species $\%$ & Remarks & Reference \\
\hline $\begin{array}{l}\text { Japan } \\
\text { Kanto }\end{array}$ & 53 & $42(79.2)$ & $\begin{array}{l}\text { E. lamae } 1.9 \\
\text { E. macusaniensis } 7.5 \\
\text { E. punoensis and/or } \\
\quad \text { E alpacae } 69.8\end{array}$ & $\begin{array}{l}53 \text { of } 390 \text { alpacas from } \\
1 \text { farm tested }\end{array}$ & Hyuga and Matsumoto (2016) \\
\hline New Zealand & 460 & $15(3.2)$ & E. macusaniensis & 5 farms were surveyed & Rawdon et al. (2006) \\
\hline $\begin{array}{l}\text { Peru } \\
\quad \text { Cuzco }\end{array}$ & 160 & $67(58.1)$ & $\begin{array}{l}\text { E. lamae } 60.4 \text {, } \\
\quad \text { E. punoesis } 30.0, \\
\text { E. alpace } 45.6 \\
\text { E. macusaniensis } 50.4\end{array}$ & $\begin{array}{l}90 \% \text { of } 2 \text { months-old } \\
\text { alpacas were positive } \\
\text { with an oocyst burden } \\
\text { of } 1016 \text { oocysts per } \\
\text { gram of feces }\end{array}$ & Guerrero et al. (1970a) \\
\hline Southern Peru & 316 & $145(46.2)$ & E. macusaniensis 56.5 & 22 herds surveyed & Cordero Ramirez et al. (2011) \\
\hline Puno & 478 & $418(87.5)$ & $\begin{array}{l}\text { E. lamae } 15.6, \\
\quad \text { E. punoesis } 20.0 \text {, } \\
\quad \text { E. alpace } 16.9 \\
\text { E. macusaniensis } 25 \\
\text { E. ivitaensis } 6.2\end{array}$ & $\begin{array}{l}<90 \text { days old healthy cria, } \\
\text { infection with multiple } \\
\text { species was common }\end{array}$ & Rodríguez et al. (2012) \\
\hline Puno & 350 & $224(64.3)$ & $\begin{array}{l}\text { E. lamae } 91, \\
\text { E. macusaniensis } 35 \text {, } \\
\text { E. punoensis } 78, \\
\text { E. alpacae } 87, \\
\text { E. ivitaensis } 13\end{array}$ & Unweaned alpacas 2 from 23 herds & Díaz et al. (2016) \\
\hline Switzerland & 72 & Not stated & E. macusaniensis & $\begin{array}{l}\text { Present in } 68 \% \text { of farms, } \\
\text { no individual animal data }\end{array}$ & Hertzberg and Kohler (2006) \\
\hline UK & Not stated & Not stated & E. ivitaensis & $\begin{array}{l}\text { Present in } 2 \text { herds. Zinc } \\
\text { sulfate sp. gr. } 1.36 \text { used } \\
\text { for flotation }\end{array}$ & Twomey et al. (2010) \\
\hline USA-10 states & 115 & $8(7.0)$ & E. macusaniensis & & Jarvinen (1999) \\
\hline Maryland & 61 & $14(26.2)$ & $\begin{array}{l}\text { E. alpacae in } 7 \text {, } \\
\text { E. punoensis in } 5 \text {, } \\
\text { mixed in } 2\end{array}$ & $\begin{array}{l}\text { Two farms. Cesium chlorite } \\
\text { sp.gr. } 1.4 \text { used for flotation }\end{array}$ & Trout et al. (2008) \\
\hline
\end{tabular}


Table 4 Prevalence of Eimeria in guanaco (Lama guanicoe)

\begin{tabular}{|c|c|c|c|c|c|}
\hline Country-region & No. tested & No. positive (\%) & Eimeria species & Remarks & Reference \\
\hline $\begin{array}{l}\text { Argentina } \\
\text { Salta }\end{array}$ & 4 & $1(25.0)$ & E. macusaniensis & Semi captive & Cafrune et al. (2009) \\
\hline Mendoza, San Juan & 35 & Not stated & $\begin{array}{l}\text { E. macusaniensis, } \\
\text { Eimeria } \mathrm{sp} .\end{array}$ & $\begin{array}{l}\text { Wild guanaco surveyed. } \\
\text { Only published as abstract }\end{array}$ & Borghi et al. (2004) \\
\hline Patagonia & 12 & $10(80.3)$ & $\begin{array}{l}\text { E. macusaniensis in } 9 \text {, } \\
\text { Eimeria } \text { spp. in } 10\end{array}$ & $\begin{array}{l}\text { Mortality due to starvation } \\
\text { in wild population. Feces } \\
\text { were from animals necropsied }\end{array}$ & Beldomenico et al. (2003) \\
\hline $\begin{array}{l}\text { Chile } \\
\text { Magallanes }\end{array}$ & 15 & $6(40.0)$ & E. macusaniensis & Semi captive & Correa et al. (2012) \\
\hline $\begin{array}{l}\text { Peru } \\
\quad 9 \text { districts }\end{array}$ & 132 & $43(33.3)$ & $\begin{array}{l}\text { E. punoensis } 21.2 \% \text {, } \\
\text { E. alpacae } 13.6 \% \text {, } \\
\text { E. lamae } 4.5 \% \text {, } \\
\text { E. macusaniensis } 15.9 \%\end{array}$ & Wild population & Castillo et al. (2008) \\
\hline USA-10 states & 27 & $2(7.4)$ & E. macusaniensis & & Jarvinen (1999) \\
\hline
\end{tabular}

\section{Clinical infections}

Little is known of camelid coccidiosis in the wild (Leguía 1991; Mamani Paredes et al. 2009; Cafrune et al. 2014). However, Eimeria infections can be pathogenic in camelids dependent on age, concurrent infections, environmental conditions, stress of captivity and transportation, and nutrition in general (Díaz et al. 2016). Some of these factors have been investigated.

Reports of clinical coccidiosis in camelids are summarized in Table 6. Except for a report of coccidiosis in a captive guanaco from the USA (Hodgin et al. 1984), all clinical reports were in llamas and alpacas.

Among reports summarized in Table 6, a comprehensive investigation of causes of mortality was performed on 15 llamas, and 34 alpacas submitted to the Oregon Diagnostic Laboratory, Oregon State University hospital during 2002 2006 (Cebra et al. 2007). The following is the most important information from this paper:

(a) E. macusaniensis infections were diagnosed in 49 camelids 3 weeks to 18 years old. The clinical signs were weight loss, lethargy, and diarrhea. Of these, 10 llamas and 9 alpacas were examined at necropsy.

(b) Feces or intestinal contents of 42 camelids were examined by flotation; E. macusaniensis oocysts were not found in 17 but E. macusaniensis-associated enteritis was confirmed histologically. The other Eimeria oocysts identified were: E. lamae and E. alpacae.

Table 5 Prevalence of Eimeria in vicuñas (Lama vicugna)

\begin{tabular}{|c|c|c|c|c|c|}
\hline Country-region & No. tested & No. positive (\%) & Eimeria species & Remarks & Reference \\
\hline $\begin{array}{l}\text { Argentina } \\
\text { Jujuy }\end{array}$ & $\begin{array}{l}81 \text { juveniles } \\
154 \text { adults }\end{array}$ & $\begin{array}{l}81(100.0) \\
143(92.8)\end{array}$ & $\begin{array}{l}\text { E. punoensis }(100 \%), \text { E. alpacae } \\
\quad(85.1 \%), \text { E. lamae }(48.1 \%), \\
\text { E. macusaniensis }(82.7 \%), \\
\text { and E. ivitaensis. }(3.7 \%) \\
\text { E. punoensis }(89.6 \%), \text { E. alpacae } \\
\quad(66.8 \%), \text { E. lamae }(27.2 \%), \\
\text { E. macusaniensis }(15.5 \%), \\
\text { and E. ivitaensis. }(1.2 \%)\end{array}$ & $\begin{array}{l}\text { Born and raised at an } \\
\text { experimental station. } \\
\text { Prevalences were } \\
\text { higher in May versus } \\
\text { in November, 2011. } \\
\text { All were asymptomatic. } \\
\text { Mixed infections were } \\
\text { common }\end{array}$ & Cafrune et al. (2014) \\
\hline $\begin{array}{l}\text { Bolivia } \\
\text { Apolobamba }\end{array}$ & $\begin{array}{l}25 \text { adults } \\
7 \text { juveniles }\end{array}$ & $\begin{array}{l}22(88) \\
7(100)\end{array}$ & $\begin{array}{l}\text { E. alpacae } 88 \% \text {, E. puneonsis } \\
80.0 \% \text {, E. lamae } 12 \% \text {, and } \\
\text { E. macusaniensis } 8 \% \\
\text { E. alpacae } 100 \%, \text { E. puneonsis } \\
\text { 100\%, E. lamae } 42.9 \% \text {, and } \\
\text { E. macusaniensis } 14.3 \%\end{array}$ & Wild population & Beltrán-Saavedra et al. (2011) \\
\hline $\begin{array}{l}\text { Peru } \\
\quad \text { Pampa Galeras }\end{array}$ & 39 Adults & $15(41.0)$ & E. punoensis/E. lamae & Wild population, opg $(<48)$ & Bouts et al. (2003) \\
\hline
\end{tabular}


Table 6 Summary of reports of clinical Eimeria infections in South American camelids

\begin{tabular}{|c|c|c|c|c|}
\hline Country & Host & Eimeria spp. & Main findings & Reference \\
\hline Australia & Alpaca & E. macusaniensis & $\begin{array}{l}\text { A } 10 \text {-year-old alpaca died suddenly without prior clinical } \\
\text { signs. Severe, necrotic enteritis with massive parasitization } \\
\text { of small intestine. No evidence for clostridial or other } \\
\text { toxins. Oocysts in feces were } 80-82 \times 50-52 \mu \mathrm{m} \text { and } \\
\text { sporocysts were } 34 \times 18 \mu \mathrm{m}\end{array}$ & $\begin{array}{l}\text { Lenghaus } \\
\text { et al. (2004) }\end{array}$ \\
\hline Germany & Llama & E. macusaniensis & $\begin{array}{l}\text { Thirteen of } 16 \text { one to three year-old llamas developed diarrhea and died within } 2 \\
\text { months after a long distance travel from northern Germany to Bavaria. } \\
\text { Enteritis associated with E. macusaniensis was found in three llamas } \\
\text { necropsied. }\end{array}$ & $\begin{array}{l}\text { Hänichen et al } \\
\text { (1994) }\end{array}$ \\
\hline $\begin{array}{l}\text { New } \\
\quad \text { Zealand }\end{array}$ & Alpaca & E. macusaniensis & $\begin{array}{l}\text { A } 10 \text {-year-old female alpaca diagnosed with histologically } \\
\text { confirmed ulcerative coccidial enteritis affecting ileum } \\
\text { and rare parasitism in duodenum. Endogenous stages } \\
\text { (schizonts, gamonts, oocysts) were present in histological } \\
\text { sections. Oocysts were seen antemortem and the alpaca } \\
\text { had been treated with an unspecified anticoccidial drug }\end{array}$ & $\begin{array}{l}\text { Rawdon } \\
\text { et al. (2006) }\end{array}$ \\
\hline \multicolumn{5}{|c|}{ (1) } \\
\hline Puno & Alpaca & Eimeria spp. & $\begin{array}{l}\text { Heavy coccidiosis in a 5-month-old alpaca. Schizonts and } \\
\text { gamonts of E. lamae and E. ivitaensis found in histological } \\
\text { sections }\end{array}$ & $\begin{array}{l}\text { Guerrero } \\
\quad \text { et al. (1967) }\end{array}$ \\
\hline $\begin{array}{l}\text { Southern } \\
\text { sierra }\end{array}$ & Alpacas & E. macusaniensis & $\begin{array}{l}\text { Twelve 25-35-day-old alpacas that died suddenly }(n=4) \text { and } \\
8 \text { with diarrhea were necropsied and studied histologically. } \\
\text { Macroscopic and microscopic lesions were seen in jejunum } \\
\text { and ileum. Necrosis, fusion and blunting of villi were } \\
\text { associated with schizonts and gamonts, and oocysts }\end{array}$ & $\begin{array}{l}\text { Rosadio and } \\
\text { Ameghino } \\
\text { (1994) }\end{array}$ \\
\hline $\begin{array}{l}\text { IVITA, } \\
\text { La } \\
\text { Raya, } \\
\text { Cusco }\end{array}$ & Alpaca & $\begin{array}{l}\text { E. macusaniensis, } \\
\text { E. lamae, } \\
\text { E punoensis; } \\
\text { E. ivitaensis }\end{array}$ & $\begin{array}{l}\text { Investigations of causes of diarrhea in } 48 \text { newborn alpacas } \\
\text { found entrotoxemia in } 30 \text {, collibacillosis in } 7 \text {, and Eimeria } \\
\text { in } 11 ; \text {. macusaniensis in } 4, E \text {. macusaniensis and } E \text {. } \\
\text { punoensis in } 7 \text {, and E. lamae in } 4 \text {. Authors mentioned } \\
\text { finding E. macusaniensis stages in small intestine, cecum, } \\
\text { and colon. Intracellular stages of E. ivitaensis were reported } \\
\text { in crypts of jejunum and ileum for the first time }\end{array}$ & $\begin{array}{l}\text { Palacios } \\
\text { et al. }(2005)\end{array}$ \\
\hline $\begin{array}{l}\text { Marang- } \\
\text { ani, } \\
\text { Cusco }\end{array}$ & Alpaca & $\begin{array}{l}\text { E. macusaniensis; } \\
\text { E. ivitaensis }\end{array}$ & $\begin{array}{l}\text { Sudden onset of diarrhea, emaciation, and death in seven } \\
\text { 4-5-month-old alpacas from one herd. Enteritis was the } \\
\text { main finding. E. macusaniensis stages were found in } \\
\text { jejunum, ileum, cecum, and ascending colon whereas } \\
\text { E. ivitaensis stages were restricted to jejunum and ileum. } \\
\text { Schizonts, gamonts, and oocysts were identified for both } \\
\text { species; schizonts of E. ivitaensis caused more damage } \\
\text { than schizonts of E. macusaniensis. Microgamonts of both } \\
\text { species appeared similar but gamonts were different; the } \\
\text { wall forming bodies of E. ivitaensis were small and } \\
\text { basophilic whereas those of E. macusaniensis were large } \\
\text { and eosinophilic }\end{array}$ & $\begin{array}{l}\text { Palacios et al. } \\
(2004,2006)\end{array}$ \\
\hline $\begin{array}{l}\text { Arequip- } \\
\text { a, } \\
\text { Puno, } \\
\text { Cusco }\end{array}$ & Alpaca & E. macusaniensis & $\begin{array}{l}\text { Histological evaluation of } 108 \text { cases of Clostridium-induced } \\
\text { enterotoxemia in 2-8-week-old alpacas revealed (a). } \\
\text { E. macusaniensis in } 33(30.5 \% \text { ). (b) massive infection in } 3 \\
\text { of } 31 \text { alpacas less than } 2 \text { weeks old; } 2 \text { of these were only } 10 \\
\text { days old. (c) infections observed even in well managed herd. } \\
\text { (d) severe lesions in jejunum and ileum in crypts }\end{array}$ & $\begin{array}{l}\text { Rosadio } \\
\quad \text { et al. (2010) }\end{array}$ \\
\hline $\begin{array}{l}\text { Silli, } \\
\text { Cusco }\end{array}$ & Alpaca & Eimeria $\mathrm{sp}$. & $\begin{array}{l}\text { Causes of diarrhea in an outbreak involving } 501 \text { - to } 5 \text {-week-old } \\
\text { alpacas were investigated. } 80 \% \text { had Eimeria spp. infections; } \\
\text { alone in 19, and in combinations with other agents in } 21 \\
\text { alpacas. Illustrations from a } 21 \text {-day-old alpacas show heavy } \\
\text { coccidial infections, different from E. macusaniensis }\end{array}$ & $\begin{array}{l}\text { Rojas et al. } \\
\text { (2016) }\end{array}$ \\
\hline UK & Alpaca & $\begin{array}{l}\text { Oocysts of } \\
\text { E. macusaniensis, } \\
\text { Elamae, and } \\
\text { E. alpace in feces }\end{array}$ & $\begin{array}{l}\text { The index case, a 16-month-old alpaca, was found dead with a } \\
\text { short period of restlessness. Histologic examination revealed } \\
\text { acute, necrotic enteritis with Clostridium perfringens toxemia. } \\
\text { Lesions associated E. macusaniensis stages. }\end{array}$ & $\begin{array}{l}\text { Schock } \\
\quad \text { et al. (2007) }\end{array}$ \\
\hline
\end{tabular}


Table 6 (continued)

\begin{tabular}{|c|c|c|c|c|}
\hline Country & Host & Eimeria spp. & Main findings & Reference \\
\hline & & & $\begin{array}{l}54 \text { additional cases of coccidiosis recorded; } 40 \text { confirmed, } 9 \\
\text { suggestive, and } 5 \text { incidental. Most cases were in adults. Of } \\
\text { the } 26 \text { with established diagnosis, } 10 \text { were associated with } E \text {. } \\
\text { macusaniensis, } 7 \text { with } E \text {. punoensis, } 1 \text { with } \text { E. alpacae, } 1 \text { with } \\
\text { E. lamae; mixed Eimeria spp. in } 7 .\end{array}$ & \\
\hline \multicolumn{5}{|l|}{ USA } \\
\hline Michigan & Guanaco & E. macusaniensis & $\begin{array}{l}\text { 3-month-old female guanaco from Detroit Zoological Park } \\
\text { died of acute illness with leptospiral nephritis and hepatitis. } \\
\text { The animal had abdominal pain. At necropsy a } 60 \mathrm{~cm} \text { section } \\
\text { of jejunum was congested. Histologically, it had subacute } \\
\text { enteritis with gamonts and oocysts of } E \text {. macusaniensis; } \\
\text { feces were not available for oocyst identification. }\end{array}$ & $\begin{array}{l}\text { Hodgin } \\
\quad \text { et al. (1984) }\end{array}$ \\
\hline Wyoming & Llama & E. macusaniensis & $\begin{array}{l}\text { 3-year-old female llama died after short illness associated with } \\
\text { enterotoxemia. Asexual and sexual stages reported in ileum. } \\
\text { E. macusaniensis oocysts found in feces }\end{array}$ & $\begin{array}{l}\text { Schrey } \\
\quad \text { et al. (1991) }\end{array}$ \\
\hline Missouri & $\begin{array}{l}\text { Alpaca or } \\
\text { llama not } \\
\text { distinguished }\end{array}$ & Eimeria sp. & $\begin{array}{l}2 \text { alpacas with weight loss and hypoproteinemia. Both had been } \\
\text { vaccinated against } C \text {. perfrigens. First alpaca 10-year-old } \\
\text { diagnosed antemortem with } E \text {. macusaniensis based on jejunal } \\
\text { biopsy died } 5 \text { days despite of treatment with sulfadimethoxine. } \\
\text { The alpaca had chronic weight loss. Coccidial stages found in } \\
\text { jejunum and ileum. The second animal died after diarrheal } \\
\text { episode. Necropsy revealed Eimeria stages in jejunum and } \\
\text { ileum but no oocysts in feces }\end{array}$ & $\begin{array}{l}\text { Chigerwe } \\
\text { et al. (2007) }\end{array}$ \\
\hline $\begin{array}{l}\text { New } \\
\text { York }\end{array}$ & Alpaca & E. macusaniensis & $\begin{array}{l}\text { Two-year-old female alpaca with abdominal pain, hypoproteinemia. } \\
\text { Ultrasound examination revealed thickened loop of small intestine } \\
\text { with collapsed lumen. Histological examination of biopsied small } \\
\text { intestinal area revealed severe parasitism with E. macusaniensis } \\
\text { stages. The alpaca recovered after sulfadimethoxine treatment. } \\
\text { Oocysts of two species of Eimeria were present in feces, } \\
\text { predominantly E. punoensis }\end{array}$ & $\begin{array}{l}\text { Johnson } \\
\quad \text { et al. (2009) }\end{array}$ \\
\hline Oregon & $\begin{array}{l}15 \text { llamas, } \\
34 \text { alpacas }\end{array}$ & E. macusaniensis & See text for details & $\begin{array}{l}\text { Cebra } \\
\quad \text { et al. (2007) }\end{array}$ \\
\hline Illinois & 1 llama & E. macusaniensis & Weight loss. Gametogony described in detail & Dubey (2018) \\
\hline
\end{tabular}

Table 7 Pathogens identified in feces of neonatal alpacas with diarrhea

\begin{tabular}{|c|c|c|c|c|c|c|c|c|c|c|}
\hline \multirow[t]{2}{*}{ Source } & \multirow[t]{2}{*}{ No. } & \multirow{2}{*}{$\begin{array}{l}\text { Age } \\
\text { (days) }\end{array}$} & \multirow[t]{2}{*}{ Year } & \multicolumn{6}{|c|}{ Percent of samples } & \multirow[t]{2}{*}{ Reference } \\
\hline & & & & E. coli & $\begin{array}{l}\text { Corona } \\
\text { virus }\end{array}$ & $\begin{array}{l}\text { Cryptosp } \\
\text { oridium }\end{array}$ & Giardia & $\begin{array}{l}\text { Rota } \\
\text { virus }\end{array}$ & Eimeria & \\
\hline Oregon, USA $^{\mathrm{a}}$ & 45 & $10-210$ & 1999-2002 & NS & 42 & 9 & 18 & 2 & 13 & Cebra et al. (2003) \\
\hline Ohio, USA $^{\mathrm{b}}$ & 59 & $4-120$ & 1999-2004 & 0 & 6.9 & 25.9 & 32.8 & 0 & 12.1 & $\begin{array}{l}\text { Whitehead and } \\
\text { Anderson } \\
\text { (2006) }\end{array}$ \\
\hline Puno, Peru $^{\mathrm{c}}$ & 48 & newborn & $2002-2003$ & $77^{\mathrm{f}}$ & $\mathrm{NS}^{\mathrm{e}}$ & 4.1 & NS & NS & $31.4^{\mathrm{g}}$ & $\begin{array}{l}\text { Palacios et al. } \\
\text { (2005) }\end{array}$ \\
\hline Cusco, Peru ${ }^{\mathrm{d}}$ & 50 & $7-35$ & $\begin{array}{l}\text { January-February, } \\
2010\end{array}$ & 34 & 40 & 20 & NS & 32 & 80 & Rojas et al. (2016) \\
\hline
\end{tabular}

${ }^{\text {a }}$ Oregon State University Veterinary Diagnostic Laboratory, Corvallis, Oregon, USA

${ }^{\mathrm{b}}$ Veterinary Clinical Sciences, The Ohio State University, Columbus, Ohio, USA

${ }^{\mathrm{c}}$ Facultad de Medicina Veterinaria, Universidad Nacional Mayer de San Marcos, Lima, Peru

${ }^{\mathrm{d}}$ Instituto Veterinario de Investigaciones Tropicales y de Altura (IVITA), Cuzco, Peru

${ }^{\mathrm{e}} \mathrm{NS}=$ not stated

${ }^{\mathrm{f}}$ Of the 37 cases of bacterial infection, 30 were due to enterotoxemia

$\mathrm{g}_{4}$ cases of Eimeria macusaniensis and enterotoxemia, 7 mixed infection with E. macusaniensis and E. punoensis, and 4 cases due to E. lamae 
Table 8 Experimental infections of camelids with Eimeria species

\begin{tabular}{|c|c|c|c|c|}
\hline $\begin{array}{l}\text { Host } \\
\text { species (no.) }\end{array}$ & Eimeria species & No. of oocysts & $\begin{array}{l}\text { Prepatent period } \\
\text { in days }\end{array}$ & Reference \\
\hline $\begin{array}{l}\text { Llama } \\
\text { (4) }\end{array}$ & $\begin{array}{l}\text { E. alpacae- } 25 \% \text {, } \\
\text { E. punoensis } 75 \% \text {-both from llama }\end{array}$ & $\begin{array}{l}\text { 10,000-2 llamas, } \\
50,000,2 \text { llamas }\end{array}$ & $\begin{array}{l}\text { E. alpacae-16-18, } \\
\text { E. punoensis-10 }\end{array}$ & Foreyt and Lagerquist (1992) \\
\hline $\begin{array}{l}\text { Llama } \\
(4)\end{array}$ & $\begin{array}{l}\text { E. macusaniensis- } \\
\text { Guanaco }\end{array}$ & $500-5000$ & $36-41$ & Jarvinen (2008) \\
\hline (3) & $\begin{array}{l}\text { E. macusaniensis- } \\
\text { Alpaca }\end{array}$ & 1000 & 33,34 & \\
\hline $\begin{array}{l}\text { Llama } \\
(6)\end{array}$ & $\begin{array}{l}\text { E. macusaniensis- } \\
\text { Llama and alpaca }\end{array}$ & $20,000-100,000$ & $32-36$ & Rohbeck (2006) \\
\hline $\begin{array}{l}\text { Alpaca } \\
\text { (4) }\end{array}$ & $\begin{array}{l}\text { E. macusaniensis- } \\
\text { Alpaca and llama }\end{array}$ & 20,000 & 31 or 35 & Cebra et al. (2012) \\
\hline
\end{tabular}

${ }^{\mathrm{a}}$ Source of infection is in bold

(c) Multiple sections of intestines were available for histological examination in 29 of 34 cases of E. macusaniensis. Eimeria macusaniensis lesions were most severe in jejunum and ileum. Meronts, macro and micro-gamonts, and oocysts were reported in histological sections; the identification of species was based on large size of wall-forming bodies in developing gamonts and oocysts found. (d) Early gamonts, but no mature gamonts, were detected in 13 camelids in whose feces oocysts were not demonstrable.

(e) Most interesting information was obtained from outbreaks of coccidiosis in 15 camelids on four farms. One outbreak occurred in a group of alpacas, 20 days after being introduced to new premises that had been vacant for 6 months. Six additional alpacas became ill within

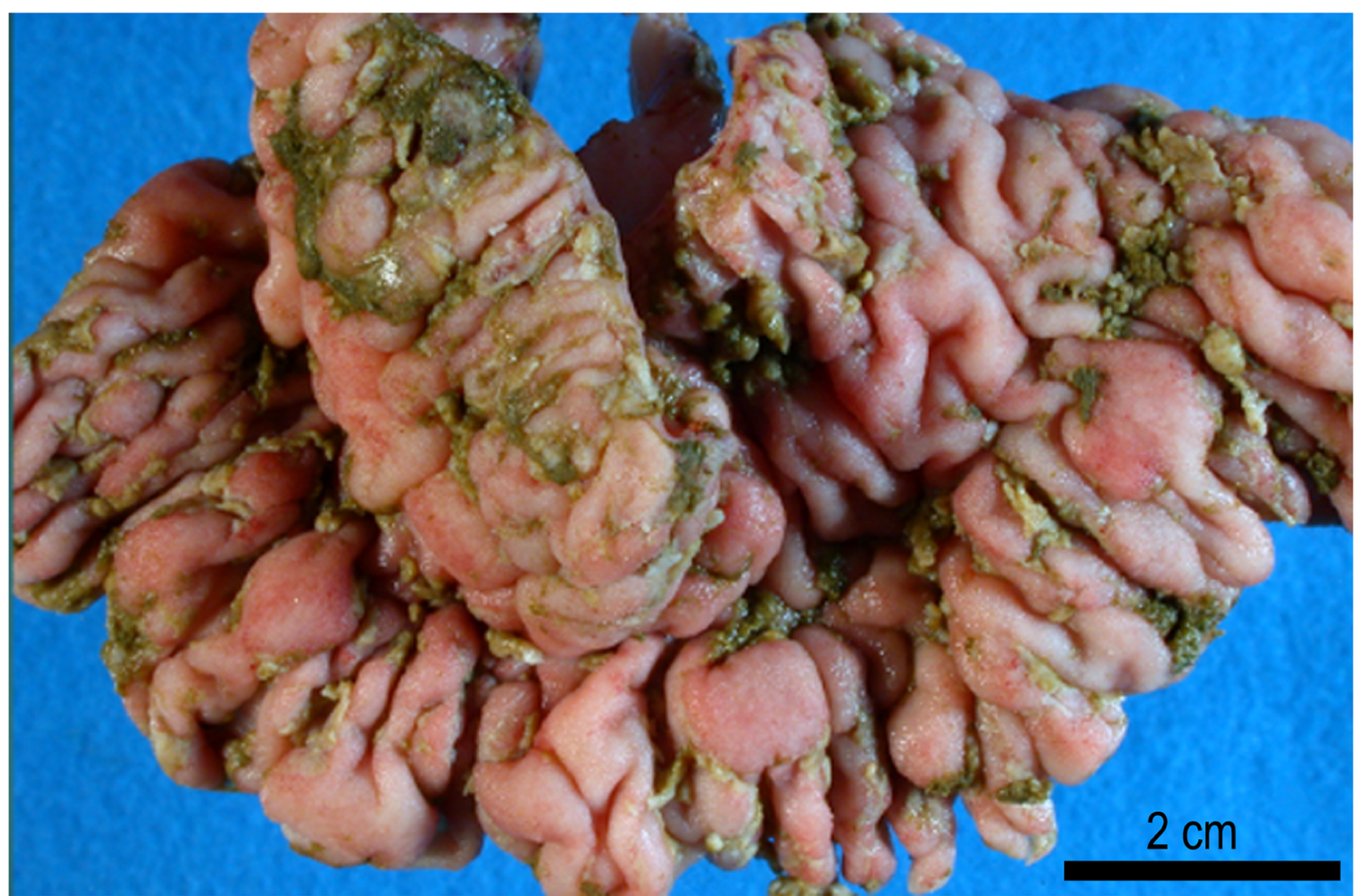

Fig. 2 Proliferative enteritis in ileum of an alpaca. This animal had concurrent Salmonella infection. Courtesy of Prof. Robert Bildfell, Oregon State University, Corvallis, USA 


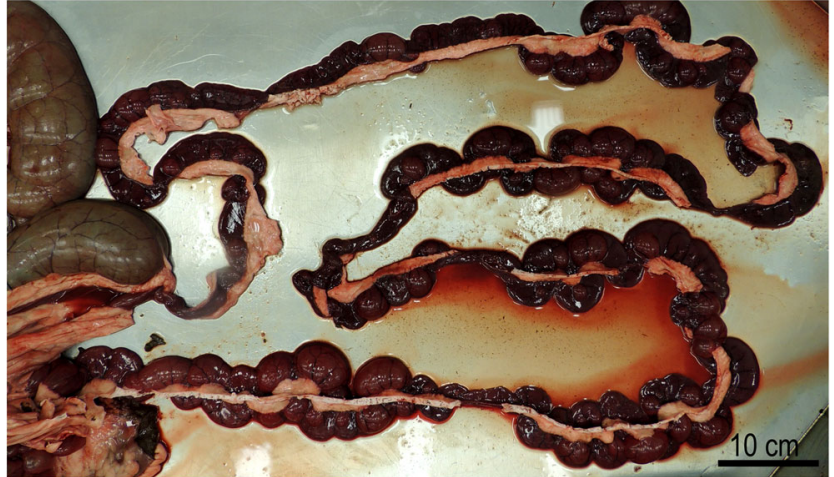

Fig. 3 Small intestine of a 7 years-old pregnant alpaca that died with a severe hemorrhagic enteritis attributed to Eimeria macusaniensis. Courtesy of Dr. Gerald E. Duhamel, Cornell University, Ithaca, New York
13 days; four of these died and were necropsied. Eimeria macusaniensis was diagnosed histologically. Eimeria macusaniensis oocysts were detected in feces of five alpacas 37 days after move to the new premises; these alpacas had diarrhea. The resident alpacas moved to the same pasture at the same time remained healthy.

(f) This investigation concluded that E. macusaniensisassociated coccidiosis is common cause of illness in camelids of all ages in Oregon.

\section{Concurrent infections and other causes of mortality}

During a retrospective study of 3766 alpacas that had died between 1998 and 2000 in three production centers in Peru,

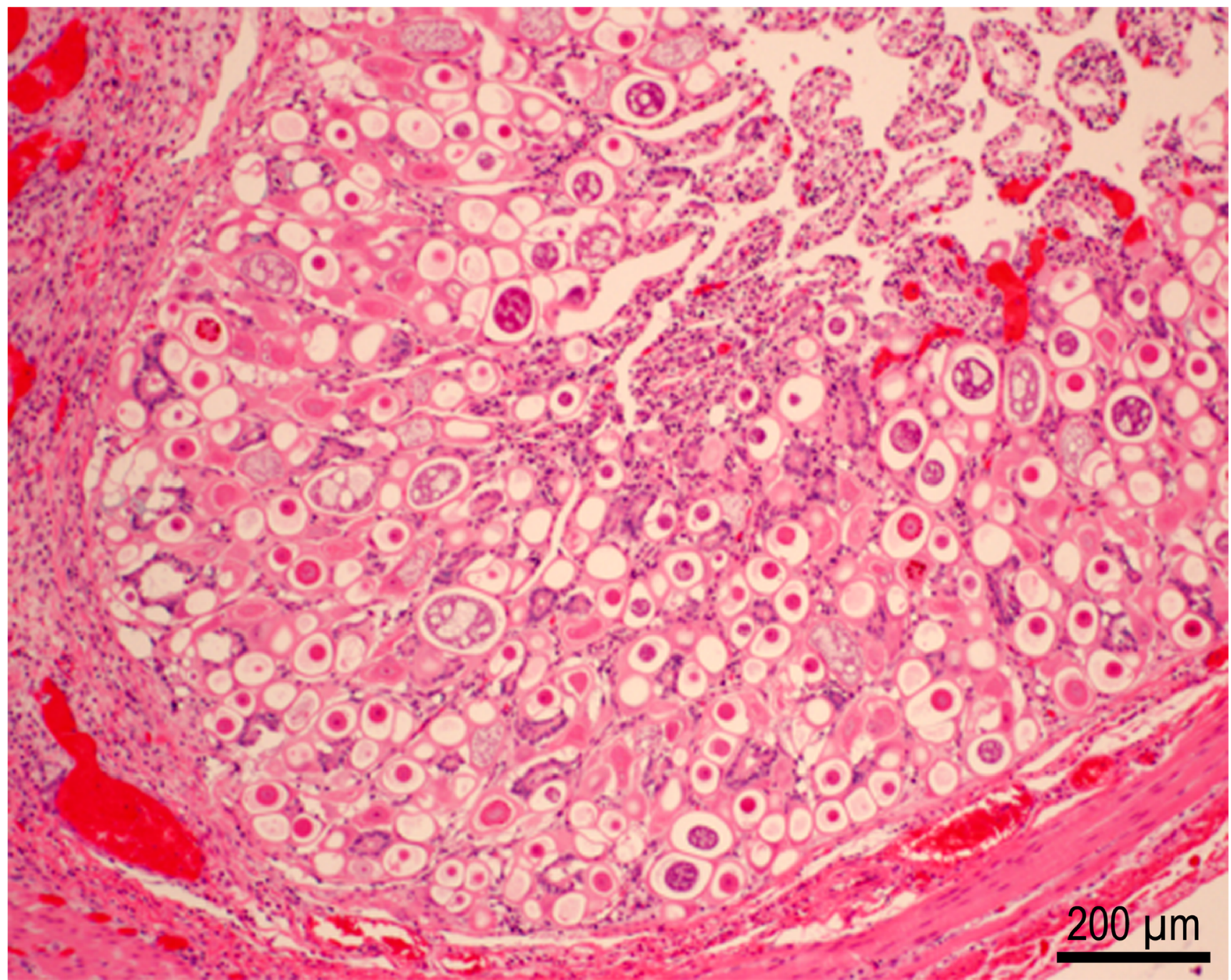

Fig. 4 Massive infection of Eimeria macusaniensis small intestine of a 7month-old alpaca from Indiana, USA (OSU case 07-1238). This animal also had histologically verified enterotoxemia in other sections of small intestine. The gamonts are immature and there are no oocysts. Hematoxylin and eosin stain. Courtesy of Prof. Michael Oglesbee, The Ohio State University, Columbus, USA 


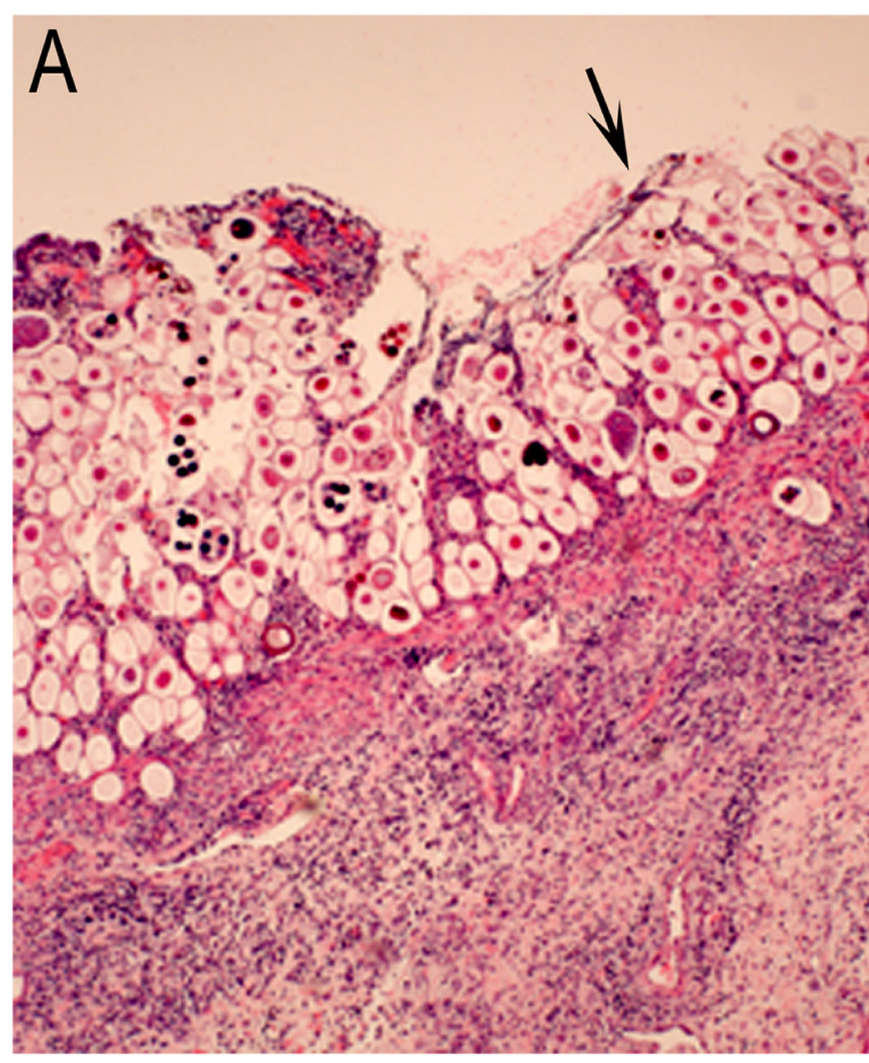

Fig. 5 Biopsy of jejunum from a 2-year-old female alpaca with severe enteritis associated with Eimeria macusaniensis (Johnson et al. 2009). Hematoxylin and eosin stain. Courtesy of Dr. Gerald E. Duhamel, Cornell University, Ithaca, New York. Arrows point to loss of surface

parasitic disease accounted for 3.0\%; $51.7 \%$ of deaths were attributed to infectious causes (Mamani Paredes et al. 2009). Among the parasitic diseases, coccidiosis was found in $25.4 \%$. Thus, coccidiosis was recognized as cause of mortality only in few alpacas. However, a critical evaluation of etiology was lacking in this investigation.

Neonatal diarrhea is a common problem in raising livestock and diagnosis is problematic because of multiple etiology. Examples of pathogens found in cases of neonatal diarrhea in camelids are shown in Table 7. Despite all referred pathogens that can cause diarrhea, their relative importance is difficult to determine. An unusually severe outbreak of diarrhea was investigated in an alpaca herd in Silli, Cusco, Peru (Table 7). Of 50 affected alpacas, 6 died and 44 were euthanized; all were examined at necropsy (Rojas et al. 2016). Histologically, 44 of 50 alpacas had enteritis and $80 \%$ had Eimeria sp. infections. It is uncertain whether the diagnosis of Eimeria infections was based solely on fecal testing or histology. One illustration (Fig. 3 of Rojas et al. 2016) of small intestine shows heavy coccidiosis with small-sized Eimeria but there was no mention of species involved or description of parasitic stages (my attempts to obtain more information about endogenous stages were unsuccessful).

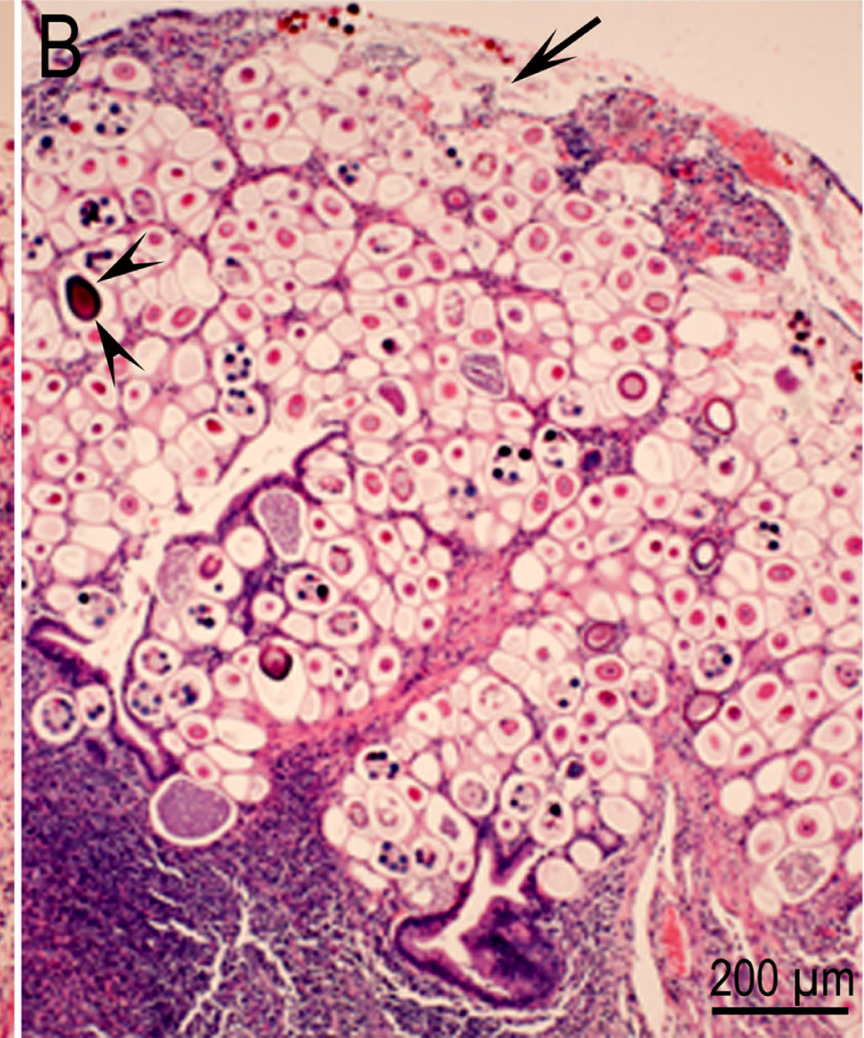

villar mucosal structures. A The mucosa is replaced with gamonts and oocysts. Note severe inflammation within the underlying submucosa. B Higher magnification shows ulcerative enteritis. Note an oocyst (arrowheads)

In an enquiry of causes of neonatal deaths in young alpacas (2-4 months old) from three alpaca centers in Peru, histological sections of intestine of 108 alpacas considered to have died from enterotoxemia were examined for evidence of E. macusaniensis infection. Only sections of intestines from grossly visible lesions were examined. Most $(n=103)$ sections were from the ileum with only five from jejunum. Eimeria macusaniensis developmental stages were detected in 33 alpacas. Of the 31 alpacas with available ages, three were 2 weeks old; two were only 10 days old (Rosadio et al. 2010). These findings indicate that alpacas can become infected on the day of birth because the minimum prepatent period of any camelid Eimeria is 10 days (Table 8).

Coinfection of coccidiosis and enterotoxemia were associated with mortality in newborn alpacas in another report (Palacios et al. 2005, Table 7).

\section{Stress}

Housing in close quarters and poor nutrition are some of the complicating factors in coccidiosis. Stress of transportation and change of ownership/location can 


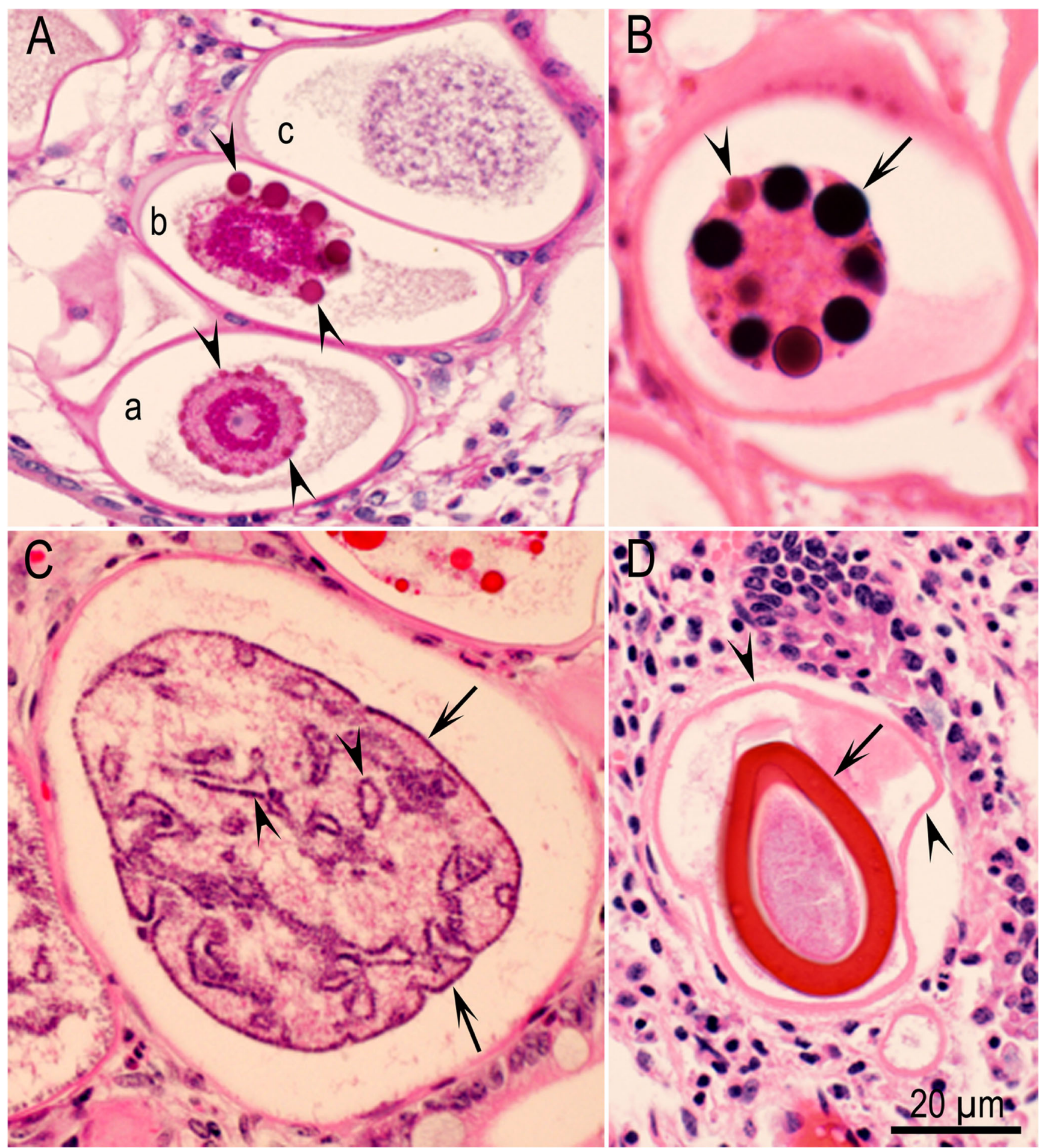

Fig. 6 Gamonts and oocysts of Eimeria macusaniensis in sections of small intestine of llama. A Note intracellular gamonts. (a) Early macrogamont with PAS-positive (amylopectin granules) around the central nucleus, and small-sized wall forming bodies (WFB, arrowheads). (b) More advanced macrogamont with WFB (arrowheads). (c) Immature microgamont with many nuclei. PAS-counter stained with hematoxylin.
B Macrogamont with different sized WFB (arrow, arrowhead). Hematoxylin and eosin stain. C Microgamont with numerous nuclei arranged at the periphery (arrows) or centrally (arrowheads). D An intracellular oocyst. Note, sporont filling the interior of the oocyst, thick oocyst wall (arrow), truncated anterior micropylar end, and thick parasitophorous vacuole (arrowheads). Hematoxylin and eosin stain predispose camelids to coccidiosis. Shows, sales, and movement for breeding, and the management in the new farm can cause stress. In one instance, 30 llamas developed clinical coccidiosis after being transported to 
a new farm (Cebra et al. 2007). Adult alpacas have developed fatal coccidiosis within 5 weeks after transportation to a new farm (Chigerwe et al. 2007; Johnson et al. 2009).

\section{Diagnosis}

\section{Antemortem}

Lethargy, diarrhea, abdominal distention, anorexia, weight loss, constipation, and colic have been reported in camelids with uncomplicated coccidiosis (Costarella and Anderson 1999; Cebra et al. 2007; Johnson et al. 2009). Coccidiosis should be suspected with these signs in camelids. Additionally, several camelids suffering from coccidiosis died suddenly (Rosadio and Ameghino 1994; Lenghaus et al. 2004; Palacios et al. 2006; Schock et al. 2007). It should be noted that diarrhea is an inconsistent finding, especially in adult camelids (Cebra et al. 2014).

\section{Fecal examination}

The detection of oocysts in feces can help diagnosis. Although most coccidian oocysts float in sugar or salt solutions with specific gravity (sp. gr.) of 1.28, E. macusaniensis oocysts are large and heavy and do not float well in these solutions (Cebra and Stang 2008). Solutions of sp. gr. > 1.28 are recommended for floatation of this Eimeria species. Super saturated sugar solution (sp. gr. 1.33, Johnson et al. 2009), saturated zinc sulfate solution (sp.gr. 1.36, Twomey et al. 2010), Cesium chlorite solution (sp. gr. 1.4, Trout et al. 2008) or mixed salt solutions (zinc chloride $105 \mathrm{~g}, \mathrm{NaCl} 20 \mathrm{~g}$, water to $100 \mathrm{ml}$, sp. gr. 1.59, Cafrune et al. 2009) are some examples of flotation solutions. The sedimentation methods used for trematode ova are as effective as the flotation method (Rohbeck 2006). The number of oocysts detected does not correlate with clinical signs (Foreyt and Lagerquist 1992; Costarella and Anderson 1999; Beldomenico et al. 2003; Cebra et al. 2007; Jarvinen, 2008; Foreyt and Lagerquist 1992; Rohbeck 2006; Cafrune et al. 2014). Some cases of coccidiosis may be missed because of the development of clinical signs before oocysts are excreted in feces (prepatent phase). To alleviate this problem, Cebra et al. (2012) developed a polymerase chain reaction (PCR) test for E. macusaniensis and E. lamae diagnosis. In experimentally infected alpacas, oocyst DNA was detectible up to 7 days before oocyst detection in feces. The internal transcribed primers (ITS) were species-specific without cross detection of E. macusaniensis and E. lamae. Finding Eimeria oocyst DNA, 7 days before prepatent period is intriguing.

\section{Biopsy and ultrasound examination}

Ultrasound examination results revealing local distention and increased thickness of small intestine, particularly of ileum, may provide suggestive diagnosis (Costarella and Anderson 1999; Cebra et al. 2007; Johnson et al. 2009). Smears made from biopsied material can reveal the parasitic stages (Cebra et al. 2007). However, histological examination is needed to evaluate lesions (Cebra et al. 2007; Chigerwe et al. 2007; Johnson et al. 2009).

\section{Other laboratory testing results}

Hypoproteinemia and hypoalbuminemia are the most consistent finding (Cebra et al. 2007). Hyponatremia is also relatively common, and a rare finding in camelids without some form of enteritis.

\section{Post mortem diagnosis}

Gross lesions are most common in ileum, although any region of small intestine, cecum and colon may be affected (Rosadio and Ameghino 1994; Palacios et al. 2006; Cebra et al. 2007; Johnson et al. 2009). Mucosal thickening, congestion, plaques and severe hemorrhagic enteritis may be seen in primary lesions (Figs. 2 and 3). Secondary bacterial infection can lead to severe necrotic enteritis (Cebra et al. 2007; Schock et al. 2007; Johnson et al. 2009; Rosadio et al. 2010). The bowel may also appear grossly normal, even with severe infection.

Microscopically, there is hyperplasia, non-suppurative enteritis, depending on concurrent infections (Figs. 4 and 5). Blunting, fusion, and necrosis of villi, particularly at the tips have been reported (Rosadio and Ameghino 1994; Johnson et al. 2009). Although developmental stages of camelid Eimeria occur in the mucosal epithelium and lamina propria, occasionally Eimeria and associated changes have been noted in the tunica muscularis mucosae (Johnson et al. 2009).

The detection of developing stages of coccidia can establish diagnosis of coccidiosis (Fig. 6). As stated earlier, of the five most prevalent species of Eimeria in camelids, E. macusaniensis has been most commonly identified in lesions. Its oocysts are distinctive, and it has large-sized gamonts (Figs. 4, 5, and 6). Its schizont stage is unknown (Dubey 2018). In few cases, E. ivitaensis has been associated with clinical coccidiosis in alpacas in Peru (Palacios et al. 2006) and the United States (Cebra et al. 2014; Cebra 2015).

Eimeria lamae is another pathogenic species. It is reported to develop in surface epithelium versus in crypts parasitized by E. macusianiensis and E. ivitaensis (Guerrero et al. 1967); I have not found description of endogenous stages. 


\section{Experimental infections}

In addition to experimental infections of two alpacas in Peru by Guerrero et al. (1970a) already discussed, results of four other experiments are summarized in Table 8. Main observations from experiments in Table 8 are:

(a) Minimum prepatent periods were: 31 days for E. macusaniensis, 16 days for E. lamae, and 10 days for E. punoensis (Table 8).

(b) Inoculated camelids generally remained asymptomatic despite excreting as many as 10,305 opg; peak oocyst excretion for E. lamae, and E. punoensis was during the second week of inoculation (Foreyt and Lagerquist 1992). However, 2 of 5 llama crias fed 20,000 E. macusaniensis oocysts had pulpy or watery or bloody diarrhea 3-10 or 9-16 days p.i. (Rohbeck 2006).

(c) Eimeria macusaniensis was cross transmissible between guanaco, alpaca, and llama.

(d) Eimeria macusaniensis oocysts survived for 84 months, the longest period of any known Eimeria species (Jarvinen 2008).

(e) Eimeria macusaniensis was mildly immunogenic because llamas excreted E. macusaniensis oocysts after reinoculation; in challenged llamas the prepatent period was longer (37-40 days versus 32-36 days after primary infection), patency was shorter (39-43 days versus 20 23 days after challenge) and fewer oocysts were excreted after challenge) (Rohbeck 2006).

\section{Treatment}

There are no anti-coccidial drugs approved specifically for camelids. Benzene acetonitrile compounds (ponazuril, diclazuril, toltrazuril), sulfonamides, and amprolium have been used to treat or prevent coccidiosis in camelids (Cebra et al. 2007, 2014; Ballweber 2009; Thomas and Morgan 2013; Franz et al. 2015).

Efficacy of various drugs for treating clinical coccidiosis is unknown. None of anticoccidials have any measurable effect on late stages of gamonts and oocysts that have been commonly related with clinical coccidiosis associated with E. macusaniensis and E. ivitaensis.

Treatment for coccidiosis included amprolium hydrochloride $(10 \mathrm{mg} / \mathrm{kg})$ in a $1.5 \%$ solution orally daily up to 15 days, or sulfadimethoxine $(110 \mathrm{mg} / \mathrm{kg}$ ) orally daily for 10 days, and supportive therapy. However, some camelids died despite this therapy and had confirmed coccidiosis histologically (Cebra et al. 2007). In one instance, an entire herd of 30 alpacas that developed coccidiosis 20 days after introduction to a new farm was treated with amprolium hydrochloride, two died and four were euthanized. Two of the four that died had histologically confirmed coccidiosis (Cebra et al. 2007).

The benzene acetonitrile compounds in general have low toxicity. They are used extensively to treat coccidiosis in camelids in countries where they are readily available in a convenient treatment form.

Prophylactic treatment should be considered during winter when outbreaks of coccidiosis are common. Decoquinate may be added to feed at $0.5 \mathrm{mg} / \mathrm{kg}$ /day for 4 weeks (Cebra et al. 2014).

In summary, therapeutic treatment for coccidiosis in South camelids needs validation.

\section{Conclusion and prospective}

It is evident from the above review that coccidiosis can be serious in captive camelids. Under free range/wild environment in South America, camelids can excrete numerous oocysts in feces without showing clinical signs. The pathogenesis of fatal coccidiosis is not fully understood, because even adult camelids can die suddenly, and animals can develop clinical signs long before oocysts are detected in feces. Whether there are differences in biology of Eimeria species in camelids in North America and South America needs further investigation. Among the five valid species of South American camelid Eimeria, E. macusaniensis appears to be most pathogenic. Only gamonts and oocysts have been confirmed in histological sections of intestines in cases associated with E. macusaniensis. There is need to investigate unknown endogenous stages of camelid coccidia. It appears that heavy parasitization of E. macusaniensis in crypts of ileum predisposes camelids to other enteric pathogens, particularly Clostridium perfrigens toxemia. There are no anticoccidial drugs specifically approved for use in camelids.

Acknowledgements I would like to thank Drs. R.J. Bildfell, C. Bauer, M. M. Cafrune, C. K. Cebra, A. Daugschies, P. Diaz, G. Leguía, G. A. Perkins, and R. H. Rosadio who supplied specimens and advice. I also thank Camilla Cezar, Fernando Murata, Oliver Kwok, Andressa Ferreira da Silva, and Shiv Kumar Verma in my laboratory for assistance in preparation of this review.

\section{References}

*cited by Guerrero (1967a,b)

*Arnao M (1951) Parásitos identificados en el Instituto Nacional de Biología Animal. Rev Int Nac Biol Ani, Lima 2:78-80

Ballweber LR (2009) Ecto- and endoparasites of new world camelids. Vet Clin N Am Food Anim Pract 25:295-310

Beldomenico PM, Uhart M, Bono MF, Marull C, Baldi R, Peralta JL (2003) Internal parasites of free-ranging guanacos from Patagonia. Vet Parasitol 118:71-77 
Beltrán-Saavedra LF, Nallar-Gutiérrez R, Ayala G, Limachi JM, Gonzalez-Rojas JL (2011) Estudio sanitario de vicuñas en silvestría del Área Natural de Manejo Integrado Nacional Apolobamba, Bolivia. Ecol Bolivia 46:14-27

Borghi ED, Araoz C, Jofré C, Duarte A, Mera y Sierra RL (2004) Gastrointestinal parasites of guanacos (Lama guanicoe) of Midwest Argentina (Mendoza and San Juan). Biocell 28:185

Bouts T, Fox MT, Scheres G, Chávez A (2003) Identification of gastrointestinal nematodes and coccidia in wild vicunas (Lama vicugna) in Pampa Galeras, Peru. In: Erkrankungen der Zootiere: Verhandlungsbericht des 41 Internationalen Symposiums uber die Erkrankungen der Zoo- und Wildtiere, Rome, Italy, 28 May - 1 June, pp 101-105. Symposiums

Cafrune MM, Marín RE, Rigalt FA, Romero SR, Aguirre DH (2009) Prevalence of Eimeria macusaniensis and Eimeria ivitaensis in South American camelids of Northwest Argentina. Vet Parasitol $162: 338-341$

Cafrune MM, Romero SR, Aguirre DH (2014) Prevalence and abundance of Eimeria spp. infection in captive vicuñas (Vicugna vicugna) from the Argentinean Andean Altiplano. Small Rumin Res 120:150-154

Castillo DH, Chávez VA, Hoces RD, Casas AE, Rosadio AR, Wheeler JC (2008) Contribución al estudio del parasitismo gastrointestinal en guanacos (Lama guanicoe cacsilensis). Rev Inv Vet Perú 19:168-175

Cebra CK (2015) North American experience with coccidiosis in New World camelids. Proc. VII Congresso Mundal en camélidos. Sudamericanos. Puno-Peru 2015. 5 pages. Published by Universidad Nacional del Altiplano

Cebra CK, Stang BV (2008) Comparison of methods to detect gastrointestinal parasites in llamas and alpacas. J Am Vet Med Assoc 232: 733-741

Cebra CK, Mattson DE, Baker RJ, Sonn RJ, Dearing PL (2003) Potential pathogens in feces from unweaned llamas and alpacas with diarrhea. J Am Vet Med Assoc 223:1806-1808

Cebra CK, Valentine BA, Schlipf JW, Bildfell RJ, McKenzie E, Waitt LH, Heidel JR, Cooper BJ, Löhr CV, Bird KE, Saulez MN, Firshman AM (2007) Eimeria macusaniensis infection in 15 llamas and 34 alpacas. J Am Vet Med Assoc 230:94-100

Cebra CK, Stang BV, Smith CC (2012) Development of a nested polymerase chain reaction assay for the detection of Eimeria macusaniensis in camelid feces. Am J Vet Res 73:13-18

Cebra CK, Anderson D, Tibary A, Van Saun R, Johnson LW (2014) Parasitic gastroenteritis. In: Llama and Alpaca Care, Medicine, Surgery, Reproduction, Nutrition, and Health Care, 1st edn. Saunders Elsevier, Saint Louis, pp 501-512

*Chávez CE (1959) Enfermedades parasitarias de las alpacas. An Primer Ciclo Conf Med Vet Lima

*Chávez CE (1965) Parasites and parasitic diseases of Lama pacos (alpacas) in Perú. Univ. San Marcos, Lima

*Chávez CE, Guerrero CA (1960) Parásitos de alpacas. An Primer Cong Nac Med Vet Lima 40-41

Chigerwe M, Middleton JR, Williams F, Tyler JW, Kreeger JM (2007) Atypical coccidiosis in South American camelids. J Vet Diagn Investig 19:122-125

Cordero Ramirez A, Huanca López W, Díaz Fernández P, López Sández CM, Panadero Fontán R, Fernández Rodriguez G, Lago N, Morrondo Pelayo P, Díez Baños P (2011) Infection by gastrointestinal parasites in alpacas (Lama pacos) from Southern Perú. XII Congresso Ibérico Parasitología. Zaragoza 5-8 July 2011

Correa L, Zapata B, Soto-Gamboa M (2012) Gastrointestinal and blood parasite determination in the guanaco (Lama guanicoe) under semicaptivity conditions. Trop Anim Health Prod 44:11-15

Costarella CE, Anderson DE (1999) Ileocecocolic intussusception in a one-month-old llama. J Am Vet Med Assoc 214:1672-1673

de Souza MV, da Silva LGR, Silva-Pinto V, Mendez-Quiros P, Chaves SAM, Iñiguez AM (2018) New paleoparasitological investigations from the pre-Inca to Hispanic contact period in northern Chile. Acta Trop 178:290-296

Díaz P, Panadero R, López R, Cordero A, Pérez-Creo A, López CM, Fernandez G, Díez-Baños P, Morrondo P (2016) Prevalence and risk factors associated to Eimeria spp. infection in unweaned alpacas (Vicugna pacos) from southern Peru. Acta Parasitol 61:74-78

Dubey JP (2018) Gametogony of Eimeria macusaniensis Guerrero, Hernandez, Bazalar and Alba, 1971 in llama (Lama glama). Parasitology in press: https://doi.org/10.1017/S0031182018000483

Foreyt WJ, Lagerquist J (1992) Experimental infections of Eimeria alpacae and Eimeria punoensis in llamas (Lama glama). J Parasitol 78:906-909

Franz S, Wittek T, Joachim A, Hinney B, Dadak AM (2015) Llamas and alpacas in Europe: Endoparasites of the digestive tract and their pharmacotherapeutic control. Vet J 204:255-262

Fugassa MH, Sardella NH, Taglioretti V, Reinhard KJ, Araújo A (2008) Eimeriid oocysts from archaeological samples in Patagonia, Argentina. J Parasitol 94:1418-1420

Fugassa MH, Beltrame MO, Sardella NH, Civalero MT, Aschero C (2010) Paleoparasitological results from coprolites dated at the Pleistocene-Holocene transition as source of paleoecological evidence in Patagonia. J Arch Sci 37:880-884

Guerrero CA (1967a) Coccidia (Protozoa: Eimeriidae) of the alpaca (Lama pacos). Master's thesis. University of Illinois, Urbana, Illinois, pp 1-49

Guerrero CA (1967b) Coccidia (Protozoa: Eimeriidae) of the alpaca Lama pacos. J Protozool 14:613-616

Guerrero CA, Hernandez DJ, Alva MJ (1967) Coccidiosis en alpacas. Rev Méd Vét 21:59-68

Guerrero CA, Alva J, Leguía G, Bazalar H (1970a) Prevalencia de coccidias (Protozoa: Eimeriidae) en alpacas, Lama pacos. Boletén Exptraordinario Instituto Veterinario de Investigaciones Tropicales y Altura 4:84-90

Guerrero CA, Alva J, Bazalar H, Tabacchi L (1970b) Infección experimental de alpacas con Eimeria lamae. Boletin Exptraordinario Instituto Veterinario de Investigaciones Tropicales y Altura 4:79-83

Guerrero CA, Hernandez J, Bazalar H, Alva J (1971) Eimeria macusaniensis n. sp. (Protozoa: Eimeriidae) of the alpaca Lama pacos. J Protozool 18:162-163

Hänichen T, Wiesner H, Göbel E (1994): Zur Pathologie, Diagnostik und Therapie der Kokzidiose bei Wiederkaeuern im Zoo. Verhandlungsber. Erkr. Zootiere 36: 375-380

Hertzberg H, Kohler L (2006) Prevalence and significance of gastrointestinal helminths and protozoa in south American camelids in Switzerland. Berl Münch Tierärztl Wochenschr 119:291-294

Hodgin C, Schillhorn van Veen TW, Fayer R, Richter N (1984) Leptospirosis and coccidial infection in a guanaco. $\mathrm{J}$ Am Vet Med Assoc 185:1442-1444

Hyuga A, Matsumoto J (2016) A survey of gastrointestinal parasites of alpacas (Vicugna pacos) raised in Japan. J Vet Med Sci 78:719-721

Jarvinen JA (1999) Prevalence of Eimeria macusaniensis (Apicomplexa: Eimeriidae) in midwestern Lama spp. J Parasitol 85:373-376

Jarvinen JA (2008) Infection of llamas with stored Eimeria macusaniensis oocysts obtained from guanaco and alpaca feces. J Parasitol 94:969-972

Johnson AL, Stewart JE, Perkins GA (2009) Diagnosis and treatment of Eimeria macusaniensis in an adult alpaca with signs of colic. Vet $\mathrm{J}$ 179:465-467

Leguía G (1991) The epidemiology and economic impact of llama parasites. Parasitol Today 7:54-56

Leguia PG, Casas AE (1998) Eimeria ivitaensis n. sp (Protozoa: Eimeriidae) en alpacas (Lama pacos). Revista Peruana de Parasitologia 13:59-61

Lenghaus C, O'Callaghan MG, Rogers C (2004) Coccidiosis and sudden death in an adult alpaca (Lama pacos). Aust Vet J 82:711-712 
Levine ND (1973) Protozoan parasites of domestic animals and of man. Burgess Publishing Company, Minneapolis, pp 1-406

Mamani Paredes J, Condemayta Condemayta Z, Calle Charaja L (2009) Causas de mortalidad de alpacas en tres principales centros de producción ubicados en puna seca y humeda del departamento de Puno. Revista electrónica de Veterinaria 10: http://www.veterinaria. org/revistas/redvet/n080809/080904.pdf-

Martinson E, Reinhard KJ, Buikstra JE, de la Cruz KD (2003) Pathoecology of Chiribaya parasitism. Mem Inst Oswaldo Cruz 98:195-205

Palacios EC, Tabacchi NL, Chavera CA, López UT, Santillán AG, Sandoval ChN, Pezo CD, Perales CR (2004) Eimeriosis en crías de alpacas: estudio anátomo histopatológico Rev Inv Vet Perú 15: 174-178

Palacios EC, Perales CR, Chavera CA, López UT (2005) Caracterización anátomo-histopatológica de enteropatías causantes de mortalidad en crías de alpaca. Rev Inv Vet Perú 16:34-40

Palacios CA, Perales RA, Chavera AE, Lopez MT, Braga WU, Moro M (2006) Eimeria macusaniensis and Eimeria ivitaensis co-infection in fatal cases of diarrhoea in young alpacas (Lama pacos) in Peru. Vet Rec 158:344-345

Rawdon T, McFadden A, King C, Mitchell V, Howell M (2006) Clinical findings and risk factors associated with the first report of Eimeria macusaniensis in New Zealand alpacas. Theatr Surv 33:11-15

Rickard LG, Bishop JK (1988) Prevalence of Eimeria spp. (Apicomplexa: Eimeriidae) in Oregon llamas. J Protozool 35:335-336

Rodríguez HA, Casas AE, Luna EL, Gavidia ChC, Zanabria HV, Rosadio AR (2012) Eimeriosis en crías de alpacas: prevalencia y factores de riesgo Rev Inv Vet Perú 23:289-298

Rohbeck S (2006) Parasitosen des Verdauungstrakts und der Atemwege bei Neuweltkameliden: Untersuchungen zu ihrer Epidemiologie und Bekämpfung in einer südhessischen Herde sowie zur Biologie von Eimeria macusaniensis. Justus Liebig University Giessen. Dr. med vet thesis, pp 1-131

Rojas M, Manchego A, Rocha CB, Fornells LA, Silva RC, Mendes GS, Dias HG, Sandoval N, Pezo D, Santos N (2016) Outbreak of diarrhea among preweaning alpacas (Vicugna pacos) in the southern Peruvian highland. J Infect Dev Ctries 10:269-274
Rosadio RH, Ameghino EF (1994) Coccidial infections in neonatal Peruvian alpacas. Vet Rec 135:459-460

Rosadio R, Londoñe P, Pérez D, Castillo H, Véliz A, Llanco L, Yaya K, Maturrano L (2010) Eimeria macusaniensis associated lesions in neonate alpacas dying from enterotoxemia. Vet Parasitol 168:116120

Schock A, Bidewell CA, Duff JP, Scholes SF, Higgins RJ (2007) Coccidiosis in British alpacas (Vicugna pacos). Vet Rec 160:805806

Schrey CF, Abbott TA, Stewart VA, Marquardt WC (1991) Coccidia of the llama, Lama glama, in Colorado and Wyoming. Vet Parasitol 40: $21-28$

Taglioretti V, Sardella NH, Fugassa MH (2014) Morphometric analysis of modern faeces as a tool to identify artiodactyls' coprolites. Quat Int 352:64-67

Taglioretti V, Fugassa MH, Sardella NH (2015) Parasitic diversity found in coprolites of camelids during the Holocene. Parasitol Res 114: 2459-2464

Thomas SM, Morgan ER (2013) Effect on performance of weanling alpacas following treatments against gastro-intestinal parasites. Vet Parasitol 198:244-249

Trout JM, Santín M, Fayer R (2008) Detection of assemblage A, Giardia duodenalis and Eimeria spp. in alpacas on two Maryland farms. Vet Parasitol 153:203-208

Twomey DF, Allen K, Bell S, Evans C, Thomas S (2010) Eimeria ivitaensis in British alpacas. Vet Rec 167:797-798

*Vásquez M, Marchinares C, Rojas J (1965) Relación de Enfermediades Parasitarias y Parásitos Identificados en las Diferentes Regiones del Perú (de Noviembre de 1960 a Diciembre de 1963). Ministerio de Agricultura S. I. P. A

Velázquez NJ, Burry LS, Fugassa MH, Civalero MT, Aschero CA (2014) Palynological analysis of camelid coprolites: seasonality in the use of the site Cerro Casa de Piedra 7 (Santa Cruz, Argentina). Quat Sci Rev 83:143-156

Whitehead CE, Anderson DE (2006) Neonatal diarrhea in llamas and alpacas. Small Rumin Res 61:207-215

Yakimoff WL (1934) Two new species of Coccidia: Eimeria triffitt $\mathrm{n}$. sp. of the eland (Orias canna), and Eimeria peruviana n. sp. of the llama (Lama glama). Parasitology 26:510-511 